Af Institutleder, professor Lars Bo Langsted

The aim of this article is double-sided. On the one hand it summarizes the rules on corruption in Nordic legislation. On the other hand, it focuses on the difficulties legislators face when creating restrictions against corruption more generally. Criminal legislation differs only slightly across the Nordic countries. All Nordic countries have signed the same treaties on corruption, thereby committing them to criminalize the same kinds of public, private and international bribery. The differences mainly arise from the fact that Denmark, Sweden and Finland, in accordance with the Criminal Convention on Corruption from the Council of Europe (ETS no. 173), have signaled a reservation concerning the criminalization of trading in influence. Norway has criminalized trading in influence in regard to both public and private bribery, whereas Iceland has criminalized trading in influence only when it comes to public affairs. The keyword in all countries is the word "undue". Four examples are used to illustrate how legislation works in the different countries and how it is often unclear whether an advantage is "undue" or not. Finally it is argued that corruption is extremely difficult to handle by legislation alone. We all have sympathies and dislikes when it comes to the specific people we do business with. It is therefore important not only to criminalize as a remedy for regulation, but also to look to civil and other kinds of public law in order to avoid decision-making being biased by irrelevant elements.

\title{
1. Dilemmaet
}

Der er verden over udbredt enighed hos lovgivere om, at korruption - især i varianten bestikkelse - skal være forbudt og at såvel modtager som yder af bestikkelsen skal kunne straffes. Enigheden er så stor, at det har været muligt at vedtage en række konventioner med tilslutning fra mange lande om at bestikkelse skal kunne straffes strengt ${ }^{1}$. Dette gælder ikke blot bestikkelse af egne offentligt ansatte eller virksomhedsmedarbejdere i eget land, men også grænseoverskridende bestikkelse og bestikkelse, der foregår i udlandet.

Formålet med at strafbelægge bestikkelse er at undgå, at en beslutningstager lader sig påvirke af usaglige hensyn i forbindelse med udøvelsen af sin ansættelse. Den ansatte - hvad enten det er en embedsmand eller en privat ansat - skal loyalt varetager sin arbejdsgivers interesser og må kun lade sine beslutninger påvirke af den interesse, han eller hun er sat til at varetage.

\footnotetext{
* Title in English: The Rules on Corruption in Nordic Legislation. Original in Danish.
} 
Vi er imidlertid også alle en del af et samfund, vi har gået i skole, vi har en familie, vi har venner, vi har bekendte, vi har børn, der går i børnehave eller skole, vi har forretningsforbindelser, som vi gerne vil pleje og vi har kommuner, stat og lovgiver, hvis adfærd vi ofte gerne vil påvirke i en retning, der er mest gunstig for os selv eller for de idealer eller interesser, vi nu måtte have ${ }^{2}$.

Hvor vi på den ene side ønsker at hindre varetagelse af usaglige hensyn, ønsker vi på den anden side ikke at forhindre samfundets borgere $i$ at pleje deres egne interesser ved at påvirke beslutningstagere. Det er tværtimod en del af den demokratiske proces. Vi ønsker heller ikke at gøre det umuligt at have bekendte eller forretningsforbindelser ved at lave regler, der forhindrer, at vi laver forretninger med disse mennesker, eller behandler deres sager i det offentlige. Uanset om vi måtte ønske det eller ej, kan vi ikke forhindre en sagsbehandler i det offentlige $i$ at have mere sympati for den ene klient end for den anden klient. I mindre samfund, eller i f.eks. snævre faglige kredse kender næsten alle hinanden, og i en dansk retssag, vil man kunne opleve, at dommeren og anklageren har gået på universitetet sammen, at dommeren og forsvareren tidligere har arbejdet på samme arbejdsplads, og at den tiltalte har gået i parallelklassen med en af domsmændene i folkeskolen. Vi er enige om i Norden, at noget sådant er der ikke noget "at gøre ved", og alle de implicerede føler da også, at de leverer deres ydelser og arbejdspræstation helt uden subjektiv bias på grund af deres tidligere mere eller mindre overfladiske kendskab til hinanden. Man er »professionel«.

Lovgivers dilemma mellem den sociale realitet og den ideelle uafhængighed er indlysende: hvordan trækker vi grænsen mellem det grove, der skal forhindres for enhver pris, over det, som bør undgås, men som ikke bør være strafbart, til den samfundsmæssigt acceptable eller måske ligefrem ønskværdige påvirkning, der følger af al menneskelig interaktion?

Lad os se på nogle eksempler:

Eksempel 1: En borgmester ønsker at støtte den lokale håndboldklub. Det er ikke kommunalretligt lovligt at lade kommunen yde direkte økonomisk støtte. Borgmesteren kræver af en entreprenørvirksomhed, at den skal give 1 million kroner i sponsorstøtte til håndboldklubben for at virksomheden kan få en kommunal ordre om noget byggeri.

Eksempel 2: Et containerskib fra et nordisk rederi ønsker at lægge til kaj i en afrikansk havn. Den stedlige havnefoged lader kaptajnen forstå, at havnefogeden først kan se skibet - og dermed behandle sagen - hvis han får 10 USD af kaptajnen. 
Eksempel 3: En virksomhed ønsker at få ændret en lokalplan, så det bliver lovligt at opføre et stort indkøbscenter ved en indfaldsvej. Virksomheden giver et bidrag til de partier, der har flertallet i byrådet. Bidraget ydes til den lokale partiforening.

Eksempel 4: Et firma ønsker at påvirke den ordførende i et politisk parti til at stemme for et lovforslag, der vil give firmaet nye forretningsmuligheder. Direktøren i firmaet ved, at ordføreren er ubestikkelig, så direktøren inviterer i stedet den ordførendes ægtefælle på et virksomhedsbesøg, hvor han giver ægtefællen et meget kostbart maleri og fortæller ægtefællen, hvor meget det vil betyde for virksomheden, at lovforslaget bliver vedtaget.

Eksemplerne vil blive anvendt i det følgende til illustration af regler og/eller dilemmaer

\section{Juraen - på konventionsniveau}

Hvis man tager udgangspunkt i OECD-konventionen, fastslår dennes art 1 følgende pligt:

»Each Party shall take such measures as may be necessary to establish that it is a criminal offence under its law for any person intentionally to offer, promise or give any undue pecuniary or other advantage, whether directly or through intermediaries, to a foreign public official, for that official or for a third party, in order that the official act or refrain from acting in relation to the performance of official duties, in order to obtain or retain business or other improper advantage in the conduct of international business «.

Hvis vi går lige til kernen i bestemmelsen, kan vi se, at det afgørende for om der efter konventionen kan være tale om bestikkelse eller ej, er at fordelen som tilbydes, loves eller gives skal være »undue«. Dertil kommer, at fordelen skal gives med henblik på, at opnå en "improper advantage".

Fælles for de fire ovenstående eksempler er, at yderen af fordelen ønsker at opnå noget. I konventionen tales ikke blot om »advantage«, men om »improper advantage«. Sammenholdes dette led imidlertid med det foregående led: »obtain or retain business « er der tvivl om, hvorvidt den ydelse, man ønsker, i sig selv skal være uberettiget, eller om det er tilstrækkeligt at man opnår aftalen, forretningen eller lovændringen ved hjælp af uberettigede metoder. Ifølge OECD's egen fortolkning af reglerne er sidstnævnte tilstrækkeligt ${ }^{3}$. Man skal således ikke læse ordet »other« som udtryk for et lighedstegn mellem »improper advantage« og »obtain or retain from business « men som en alternativt kvalificerende omstændighed. ${ }^{4}$ 
Denne fortolkning vil da også gøre bestemmelsen parallel til Europarådets konvention om bestikkelse, hvor det i art. 2 om ydelse af bestikkelse til offentligt ansatte, hedder: »... for him or her to act or refrain from acting in the exercise of his or her functions... og hvor det således er den blotte ageren fra den offentligt ansattes side, der er tilstrækkelig

I eksempel 1 var der tale om, at virksomheden ydede sponsorstøtte til en håndboldklub efter borgmesterens anvisning. Dette vil utvivlsomt være omfattet af beskrivelsen i konventionen, idet der er tale om en "undue advantage, den er til "a third party" og det sker for at opnå ordren fra kommunen.

Hvad angår eksempel 2, kunne det også umiddelbart se ud som om, det er omfattet. Her går ydelsen af pengene endda direkte til havnefogeden, men i kommentarerne til konventionen ${ }^{5}$, hedder det: »Small "facilitation" payments do not constitute payments made "to obtain or retain business or other improper advantage" within the meaning of paragraph 1 and, accordingly, are also not an offence. Such payments, which, in some countries, are made to induce public officials to perform their functions, such as issuing licenses or permits, are generally illegal in the foreign country concerned. Other countries can and should address this corrosive phenomenon by such means as support for programmes of good governance. However, criminalization by other countries does not seem a practical or effective complementary action.«

Eksempel 3 om bidrag til den lokale partikasse, ses ikke umiddelbart at være omfattet. Dels er der næppe tale om ydelse af en fordel » ... to a ... public official, for that official or for a third party ... «, dels er ydelse af bidrag til politiske partier en ganske sædvanlig foreteelse, som I de fleste lande nok har en særlig regulering - f.eks. om transparens - men som kun sjældent betragtes som uønsket, eller i hvert fald ikke uønsket i en sådan grad, at den er gjort strafbar.

I Eksempel 4 er modtageren af fordelen ikke den pågældende politiker, men dennes ægtefælle. Ægtefællen søges tilsyneladende hvervet som "påvirkningsagent" med det formål at få politikeren til at indtage et bestemt standpunkt. OECD-konventionen indeholder ikke regler herom, men det gør Europarådets »Criminal Law Convention on Corruption« fra $1999^{6}$, hvor der i artikel 12 er en bestemmelse om »trading in influence«. I denne bestemmelse omfatter påbuddet om strafbelæggelse bl.a. følgende: »... the promising, giving or offering, directly or indirectly, of any undue advantage to anyone who asserts or confirms that he or she is able to exert an improper influence over the decision-making of any person referred to in Articles 2, 4 to 6 and 9 to 11 in consideration thereof, whether the undue advantage is for himself or herself or for anyone else ..."

Såfremt ægtefællen påtager sig at påvirke politikeren, vil tilfældet være omfattet, men går ægtefællen blot sin vej med gaven under armen, vil det ikke være 
omfattet, idet artikel 12 kun rammer ydelse af fordele til personer, der (i min oversættelse) "... hævder eller bekræfter at han eller hun er i stand til at udøve en utilbørlig indflydelse ... " på politikeren. Det skal dog bemærkes, at det ikke er enhver form for indflydelse, der falder ind under bestemmelsen. Almindelig lobby-virksomhed falder således udenfor, idet der kræves »corrupt intent« fra påvirkningsagentens side. ${ }^{7}$

Alle de nordiske lande har tiltrådt ${ }^{8}$ såvel OECD-konventionen som Europarådets konvention, men i relation til sidstnævnte har Danmark, Finland og Sverige taget forbehold i relation til artikel 12, om påvirkningsagenter. Artikel 12 er således kun bindende for Norge og Island.

\section{Juraen - på nationalt niveau}

Hovedindholdet af de nordiske landes regulering af bestikkelse er stort set identisk, bortset fra afsmitningen af det under punkt 2 nævnte forbehold for artiklen om påvirkningsagenter i Europarådets konvention. Det gør det i denne sammenhæng mindre interessant at dvæle ved de enkelte lande og den måde disse har fået bestemmelserne indpasset i deres respektive straffelove efter den tradition og metodik, der gælder der. Inden jeg ser på de enkelte eksempler efter den nationale lovgivning, kan man dog opstille nogle skemaer med det formål at få et hurtigt overblik over, hvorledes reguleringen er i de enkelte lande ${ }^{9}$ :

Tabel 1

\begin{tabular}{|c|c|c|}
\hline \multicolumn{3}{|c|}{ Aktiv bestikkelse ${ }^{10}$ (=ydelse af bestikkelse) } \\
\hline & Offentlig ansat modtager & Privat ansat modtager \\
\hline $\begin{array}{l}\text { Danmark } \\
\text { Forbrydelsens } \\
\text { kaldenavn: } \\
\text { § 122: bestikkelse } \\
\text { § 299: retur- } \\
\text { kommission }\end{array}$ & $\begin{array}{l}\text { Straffelovens } \S 122: \\
\text { - } \quad \text { Modtagelsen skal } \\
\text { være »uberettiget« } \\
\text { - } \quad \text { Modtager skal gøre noget. } \\
\text { - } \quad \text { Bøde/fængsel indtil } 3 \text { år }\end{array}$ & $\begin{array}{l}\text { Straffelovens } \S 299, n r .2 \text { : } \\
\text { - } \begin{array}{l}\text { Modtageren skal va- } \\
\text { retage en andens } \\
\text { formueanliggender }\end{array} \\
\text { - } \quad \begin{array}{l}\text { Modtagelsen skal } \\
\text { være »pligtstridig« }\end{array} \\
\text { - } \quad \text { Bøde/fængsel indtil } 11 \frac{1}{2} \text { år }\end{array}$ \\
\hline $\begin{array}{l}\text { Norge } \\
\text { Forbrydelsens } \\
\text { kaldenavn: } \\
\text { § 276a: korrupsjon }\end{array}$ & $\begin{array}{l}\text { Straffeloven } \$ 276 a, b) \\
\text { - } \quad \begin{array}{l}\text { Modtageren skal opnå } \\
\text { en »Utilbørlig fordel« }\end{array} \\
\text { - } \quad \text { Bøde/fængsel indtil } 3 \text { år } \\
\text { - } \quad \text { Hvis groft fæng- } \\
\text { sel indtil } 10 \text { år }\end{array}$ & $\begin{array}{l}\text { Straffeloven } \S 276 a, b) \\
\text { Som offentligt ansat mod- } \\
\text { tager (utilbørlighedsbe- } \\
\text { tingelsen vil dog kunne } \\
\text { være lidt strengere ved } \\
\text { private modtagere }{ }^{11} \text { ) }\end{array}$ \\
\hline
\end{tabular}




\begin{tabular}{|c|c|c|}
\hline \multicolumn{3}{|c|}{ Aktiv bestikkelse ${ }^{10}$ (=ydelse af bestikkelse) } \\
\hline & Offentlig ansat modtager & Privat ansat modtager \\
\hline $\begin{array}{l}\text { Sverige } \\
\text { Forbrydelsens } \\
\text { kaldenavn: } \\
17 \text { kap } 7 \text { §: be- } \\
\text { stickning }\end{array}$ & $\begin{array}{l}\text { Brottsbalken } 17 \text { kap. } 7 \text { § } \\
\text { - } \quad \text { Modtageren skal opnå en } \\
\text { „Otillbörlig belöning« } \\
\text { - } \quad \text { Bøde/fængsel i } 2 \text { år } \\
\text { - } \quad \text { Hvis groft fængsel } \\
\text { fra } 6 \text { mdr. til } 6 \text { år }\end{array}$ & $\begin{array}{l}\text { Brottsbalken } 17 \text { kap. } 7 \S \\
\text { Som offentligt ansat modtager }\end{array}$ \\
\hline $\begin{array}{l}\text { Finland } \\
\text { Forbrydelsens } \\
\text { kaldenavn: } \\
16 \text { kap } 13 \S: \text { Gi- } \\
\text { vende av muta } \\
30 \text { kap } 7 \text { : givanda } \\
\text { av muta i närings- } \\
\text { verksamhet }\end{array}$ & $\begin{array}{l}\text { Strafflag } 16 \text { kap } 13 \S \\
\text { (604/2002) } \\
\text { - } \quad \begin{array}{l}\text { ägnad att påverka tjäns- } \\
\text { temannens verksamhet }\end{array} \\
\text { - } \quad \text { bøde/fængsel i indtil } 2 \text { år } \\
\text { - } \quad \text { hvis groft* fra } 4 \\
\text { mdr. Til } 4 \text { år. }\end{array}$ & $\begin{array}{l}\text { Strafflag30 kap } 7 \text { § }(769 / 1990) \\
\text { - } \quad \text { orättmätig förmån } \\
\text { - } \quad \text { ansat/ledelsesmedlem } \\
\text { /varetager andens interesser } \\
\text { - } \quad \text { for at opnå en fordel } \\
\text { - } \quad \text { Bøde/fængsel i indtil } 2 \text { år }\end{array}$ \\
\hline Island & $\begin{array}{l}\text { Hegningarlög } 109 \text { gr. } \\
\text { - } \quad \text { »ávinning, sem hann á ekki } \\
\text { tilkall til« (ydelser, som } \\
\text { han ikke er berettiget til) } \\
\text { - } \quad \text { Modtager skal gøre el- } \\
\text { ler undlade noget. } \\
\text { - } \quad \text { Bøde**/fængsel indtil } 3 \text { år }\end{array}$ & $\begin{array}{l}\text { Hegningarlög } 264 \text { gr. a. } \\
\text { - } \quad \text { ansat/ledelsesmedlem } \\
\text { - } \quad \text { «ávinning, sem hann á ekki } \\
\text { tilkall til« (ydelser, som } \\
\text { han ikke er berettiget til) } \\
\text { - } \quad \text { Modtager skal gøre el- } \\
\text { ler undlade noget } \\
\text { - } \quad \text { bøde/fængsel indtil } 2 \text { år }\end{array}$ \\
\hline
\end{tabular}

* jf. 16 kap $14 \S(563 / 1998)$, hvor værdien enten skal være betragtelig eller hvor den offentligt ansatte skal handle pligtstridigt til betydelig fordel for nogen eller til mærkbar skade eller ulempe for andre.

** Under formildende omstændigheder

Af generelle træk vedrørende den aktive bestikkelse af offentligt ansatte kan fremhæves, at det kun er strafbart for yderen af bestikkelsen, såfremt det direkte er dennes formål, at få modtageren (den offentlig ansatte) til at foretage sig en handling eller en undladelse i Danmark og Island, hvor det i Finland er tilstrækkeligt, at ydelsen er "egnet til" at få modtageren til at foretage sig noget. I Norge og Sverige vil dette forhold således alene være omfattet af den samlede utilbørlighedsvurde- 
ring. Der er således næppe den store forskel i den praktiske anvendelse af reglerne på dette punkt. I alle landene er det afgørende for strafbarheden således primært om fordelen har været "utilbørlig". Dette harmonerer med konventionernes anvendelse af ordet "undue" for at beskrive fordelen.

I de tilfælde hvor modtageren af ydelsen er privat ansat, har man i Norge og Sverige valgt den løsning at anvende samme bestemmelse som, den der gælder ved bestikkelse af offentligt ansatte - men med rum til i utilbørlighedsvurderingen at sondre, typisk således, at der skal "mere til" før ydelsen bliver utilbørlig i private retsforhold end i offentlige. Den danske bestemmelse er den snævreste, idet den kræver at den modtagende skal "varetage en andens formueanliggender". Det vil således ikke være omfattet af den danske bestemmelse, hvis man betaler en privat ansat lastvognschauffør til at køre en lille omvej eller til at yde en hurtigere service, idet en sådan chauffør typisk ikke varetager en andens "formueanliggender."

Tabel 2

\begin{tabular}{|c|c|c|}
\hline \multicolumn{3}{|c|}{ Passiv bestikkelse (=modtagelse af bestikkelse) } \\
\hline & Offentlig ansat modtager & Privat ansat modtager \\
\hline $\begin{array}{l}\text { Danmark } \\
\text { Forbrydelsens } \\
\text { kaldenavn: } \\
\S 144: \text { bestikkelse } \\
\S 299 \text { : returkom- } \\
\text { mission }\end{array}$ & $\begin{array}{l}\text { Straffelovens } \S 144: \\
\text { - } \quad \text { Modtagelsen skal } \\
\text { være »uberettiget« } \\
\text { - } \quad \text { bøde/fængsel indtil } 6 \text { år }\end{array}$ & $\begin{array}{ll}\text { Straffelovens } \S 299, n r .2: \\
\text { - } & \text { Modtageren skal va- } \\
& \text { retage en andens } \\
& \text { formueanliggender } \\
\text { - } & \begin{array}{l}\text { Modtagelsen skal } \\
\text { være »pligtstridig« }\end{array} \\
\text { - } & \text { Bøde/fængsel indtil } 11 \frac{1}{2} \text { år }\end{array}$ \\
\hline $\begin{array}{l}\text { Norge } \\
\text { Forbrydelsens } \\
\text { kaldenavn: } \\
\text { § 276a: korrupsjon }\end{array}$ & $\begin{array}{l}\text { Straffeloven § 276a, a) } \\
\begin{array}{l}\text { Modtageren skal opnå } \\
\text { en »Utilbørlig fordel« }\end{array} \\
\text { - } \quad \text { Bøde/fængsel indtil } 3 \text { år } \\
\text { - } \quad \text { Hvis groft fæng- } \\
\text { sel indtil } 10 \text { år }\end{array}$ & $\begin{array}{l}\text { Straffeloven § 276a, a) } \\
\text { Som offentligt ansat modta- } \\
\text { ger (utilbørlighedsbe- } \\
\text { tingelsen vil dog kunne } \\
\text { være lidt strengere ved } \\
\text { private modtagere) }\end{array}$ \\
\hline $\begin{array}{l}\text { Sverige } \\
\text { Forbrydelsens } \\
\text { kaldenavn: } \\
20 \text { kap } 2 \text { \$: mut- } \\
\text { brott }\end{array}$ & $\begin{array}{l}\text { Brottsbalken20 kap. } 2 \text { § } \\
\text { - } \quad \text { Otillbörlig belöning« } \\
\text { • } \quad \text { Bøde/fængsel i } 2 \text { år } \\
\text { - } \quad \text { Hvis groft fængsel } \\
\text { fra } 6 \text { mdr. til } 6 \text { år }\end{array}$ & $\begin{array}{l}\text { Brottsbalken } 20 \text { kap. } 2 \S \\
\text { Som offentligt ansat modtager }\end{array}$ \\
\hline
\end{tabular}




\begin{tabular}{|c|c|c|}
\hline $\begin{array}{l}\text { Finland } \\
\text { Forbrydelsens } \\
\text { kaldenavn: } \\
40 \text { kap } 1 \text { §: Ta- } \\
\text { gande av muta } \\
30 \text { kap } 8 \text { : tagande } \\
\text { av muta i } \\
\text { näringsverk- } \\
\text { samhet }\end{array}$ & $\begin{array}{l}\begin{array}{l}\text { Strafflag } 40 \text { kap } 1 \text { ( }(604 / 2002) \\
\text { - } \quad \text { »orättmätig förmån« } \\
\text { hvis eget initiativ }\end{array} \\
\text { - } \quad \begin{array}{l}\text { ellers »ägnad att } \\
\text { påverka tjänsteman- } \\
\text { nens verksamhet« }\end{array} \\
\text { - } \quad \text { bøde/fængsel i indtil } 2 \text { år } \\
\text { - } \quad \text { hvis groft* fra } 4 \\
\text { mdr. Til } 4 \text { år. }\end{array}$ & $\begin{array}{l}\text { Strafflag30 kap } 8 \S(604 / 2002) \\
\text { - } \quad \text { »orättmätig förmån« } \\
\text { - } \quad \text { ansat/ledelsesmedlem } \\
\text { /varetager andens interesser } \\
\text { - } \quad \text { for at opnå en fordel } \\
\text { - } \quad \text { Bøde/fængsel i indtil } 2 \text { år }\end{array}$ \\
\hline Island & $\begin{array}{l}\text { Hegningarlög } 128 \mathrm{gr} \text {. } \\
\text { • } \quad \text { "ávinning, sem hann } \\
\text { á ekki tilkall til« (ydel- } \\
\text { ser, som han ikke } \\
\text { er berettiget til) } \\
\text { (Bøde) } \\
\text { - } \quad \text { sel indtil } 6 \text { år }\end{array}$ & 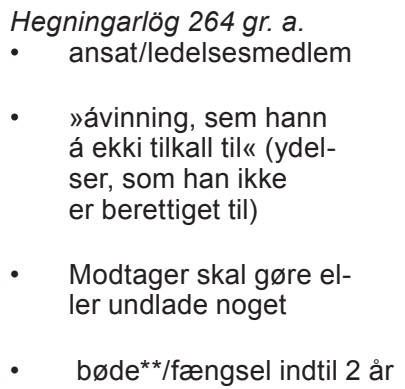 \\
\hline
\end{tabular}

* jf. 40 kap $2 \S(604 / 2002)$, hvor værdien enten skal være betragtelig eller hvor den offentligt ansatte skal handle pligtstridigt til betydelig fordel for nogen eller til mærkbar skade eller ulempe for andre.

** kun under formildende omstændigheder

Som det ses, er reglerne om modtagelse af bestikkelse stort set spejlbilleder af - i nogle tilfælde samme bestemmelse som - reglerne om ydelse af bestikkelse. Dog ses det, at i Danmark og Island er det ikke noget krav for strafbarheden for modtageren, at denne skal eller vil levere en modydelse til den aktivt bestikkende i form af en afgørelse eller lignende. Tilsvarende er det heller ikke nødvendigvis noget krav for strafbarheden for modtageren efter finsk ret.

Særegent for Danmark og Island sammenlignet med de øvrige nordiske lande er, at strafferammen for offentligt ansatte modtagere af bestikkelsen fordobles sammenlignet med strafferammen for yderen. Det er antageligt udtryk for, at det i disse lande forekommer lovgiver som værende et særligt skærpende moment, at modtageren ikke blot krænker sin "arbejdsgivers" interesser, men hele samfundets interesse i at have en pletfri embedsstand. Der er således tale om et tillidsbrud fra modtagerens side på en anden og mere gravende måde end for yderen af bestikkelsen. 
Tabel 3

\begin{tabular}{|c|c|c|}
\hline \multicolumn{3}{|c|}{ Påvirkningsagenter (trading in influence) } \\
\hline & Offentlig ansat skal påvirkes & Privat ansat skal påvirkes \\
\hline Danmark & \multicolumn{2}{|c|}{$\begin{array}{l}\text { Forbehold i forhold til Europarådets konvention, } \\
\qquad \text { art } 12 \text { udløber* } 1 / 72011\end{array}$} \\
\hline $\begin{array}{l}\text { Norge } \\
\text { Forbrydelsens } \\
\text { kaldenavn: } \\
\S 276 \mathrm{c} \text { : påvir- } \\
\text { kningshandel }\end{array}$ & 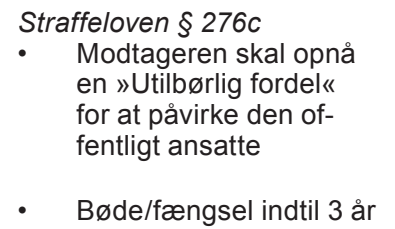 & $\begin{array}{l}\text { Straffeloven } \S 276 c \\
\text { Som ved offentlig ansat, } \\
\text { der skal påvirkes }\end{array}$ \\
\hline Sverige & \multicolumn{2}{|c|}{$\begin{array}{l}\text { Forbehold i forhold til Europarådets konvention, } \\
\qquad \text { art } 12 \text { udløber* } 1 / 102010\end{array}$} \\
\hline Finland & \multicolumn{2}{|c|}{$\begin{array}{l}\text { Forbehold i forhold til Europarådets konvention, } \\
\qquad \text { art } 12 \text { udløber* } 1 / 22012\end{array}$} \\
\hline Island & \multicolumn{2}{|c|}{$\begin{array}{l}\text { Hegningarlög } 109 \text { gr., stk. } 3 \text { og } 4 \\
\text { • „ávinning, sem hann á ekki tilkall til« (ydel- } \\
\text { ser, som han ikke er berettiget til) } \\
\text { - } \quad \text { Modtager skal ville øve** » óeðlileg áhrif« (unaturlig } \\
\text { indflydelse) på den offentligt ansattes beslutninger } \\
\text { - Bøde/fængsel indtil } 3 \text { år }\end{array}$} \\
\hline
\end{tabular}

* Forbehold kan forlænges med 3 år ad gangen

** eller give det udseende af at kunne

På området for påvirkningsagenter er der således ikke fælles fodslag mellem de nordiske lande. Sverige, Finland og Danmark har taget forbehold overfor Europarådets artikel 12, Island har foretaget en "minimumsimplementering", idet artikel 12 ikke omfatter påvirkningsagenter i private retsforhold, hvorimod Norge som det eneste nordiske land har taget skridtet fuldt ud, og indført regler om påvirkningsagenter i såvel offentlige som private retsforhold.

Det er ikke underligt, at det er her vandene skiller. Hvor det kan være vanskeligt i sig selv at vurdere, hvorledes den gennemgående utilbørlighedsbetingelse skal håndteres, bliver problemerne næsten uoverskuelige, hvis der er tale om at strafbelægge en adfærd, der er den typiske - og efterstræbelsesværdige - i en hel profession: Er man som fabrikant af kattemad interesseret i en lovændring med hensyn til det tilladte indhold af savsmuld, kontakter man en lobbyist, hvis man ikke selv har en i forvejen. Man betaler lobbyisten et honorar for at forsøge at påvirke formanden for det relevante udvalg i Rigsdagen. 
Denne beskrivelse er den helt typiske for et forløb med en lobbyist. Det er desværre også det helt typiske forløb for en påvirkningsagent. Det er antageligt også derfor tre af de nordiske lande har taget forbehold i relation til pligten til at implementere en bestemmelse om påvirkningsagenter ${ }^{12}-$ og det er givetvis forklaringen på de to grundlæggende forskellige hjemler til straf vi finder fra hhv. Norge og Island.

Efter den norske bestemmelse (straffeloven § 276c) synes ordlyden således at pege på, at det er påvirkningsagenten, der skal have en "utilbørlig" fordel, hvorimod bestemmelsen er tavs med hensyn til arten af den måde som agenten skal påvirke målpersonen. Efter den islandske regulering skal påvirkningsagenten ganske vist også have en fordel, han ikke er berettiget til, men samtidig beskrives, at den måde, agenten skal påvirke målpersonen, skal være unaturlig. Den islandske bestemmelse synes således at ramme tættere på det, der er farligt ved påvirkningsagenten. Nemlig at målpersonen bliver manipuleret eller på anden fordækt måde påvirkes til at indtage en bestemt holdning eller foretage sig bestemte dispositioner. Man kan således først se, om de penge påvirkningsagenten modtager, er bestikkelsespenge, når man ser, hvorledes agenten påvirker målpersonen. ${ }^{13}$

Udgangspunktet ved en påvirkningsagent er egentligt positivt: Målpersonen er selv ubestikkelig. Havde det ikke været tilfældet, ville den, der ønsker at målpersonen skal træffe en bestemt beslutning, jo meget enklere kunne bestikke målpersonen selv, direkte eller indirekte. Af samme grund er lobbyisme heller ikke farlig, tværtimod kan den efter min opfattelse ofte være gavnlig, idet den bidrager til at oplyse en beslutningstager om en række faktuelle forhold, som han eller hun ikke på samme måde selv kunne tilegne sig. Samtidig foregår det åbent: beslutningstageren ved at lobbyisten forfølger en bestemt interesse og derfor givetvis er subjektiv i udvælgelsen af sine fakta, men samtidig vil en lobbyists karriere kun blive kort, hvis han gribes i at fortælle egentlige usandheder.

Man vil næppe kunne ramme den egentlige påvirkningsagent med regler om medvirken, idet anvendelse af disse vil forudsætte, at der er et strafbart bestikkelsesforhold mellem beslutningstageren og den, der yder bestikkelsen.

I eksempel 4 i afsnit 1 forsøger direktøren i et firma at påvirke en ordførendes ægtefælle, ved at give ægtefællen nogle store gaver og samtidig fortælle, hvor vigtigt der er for firmaet, at den ordførende indtager en bestemt holdning.

Uanset hvorledes ægtefællen stiller sig til dette implicitte forslag om en påvirkningsaftale, vil den ikke kunne være strafbar efter dansk, svensk og finsk ret. Den vil muligvis kunne rammes af såvel norsk som islandsk ret, men for at kunne afgøre dette, mangler eksemplet oplysninger om, hvorledes de implicerede personer forestiller sig ægtefællens påvirkning af den ordførende. Efter det ovenfor anførte vil det således være afgørende, hvorledes denne påvirkning tænkes udført. 
Hvis ægtefællen tilfældigt over middagsbordet gennem en længere periode skal "tale firmaets sag" uden at nævne gaverne, vil der kunne være et forhold, der taler for, at situationen er omfattet af reglerne. Det vil formentlig påvirke bedømmelsen af "utilbørligheden/unaturligheden" af påvirkningen, at agenten er den ordførendes ægtefælle, og at den ordførende derfor antageligt er meget mere lydhør - og meget mindre på vagt - overfor de synspunkter, der fremføres ${ }^{14}$. Og i hvert fald langt mere lydhør, end hvis det var direktøren selv eller en egentlig lobbyist, der forsøgte at påvirke den ordførende.

\section{4. "Uberettiget«}

Som det fremgået er det strafferetlige forsøg på at præcisere, hvornår korruption i bred forstand bliver strafbar bestikkelse, i alle landene (gennem mere eller mindre direkte oversættelser af "undue") blevet ordet uberettiget (utilbørlig, otillbörlig, orättmätig) og den sammenfattende vægtning, der indgår i dette ord.

Der er tale om en retlig standard - det vil sige et ord, der udfyldes af retspraksis i samspil med samfundet, herunder teorien, og som forandres over tid og er forskellig fra sted til sted. Man kan naturligvis diskutere om anvendelse af en sådan standard i en straffebestemmelse (der endda giver mulighed for særdeles streng straf) er overensstemmende med de almindelige krav til straffebestemmelsers klarhed. På den anden side må man erkende, at der findes mange områder, hvor vi er nødt til ${ }^{15}$ at have straffebestemmelser, og hvor man ikke meningsfyldt kan være mere præcis fra lovgivers side.

De to yderpoler i vurderingen kan vel bedst illustreres af en politiker, hvis stemme i Parlamentet er afgørende for et lovforslags vedtagelse eller forkastelse. Det er en helt central del af demokratiet at borgerne har mulighed for at påvirke deres politikere - og i en situation som den beskrevne vil påvirkningsønsket givetvis være stort og markant. Borgerne må demonstrere, de må skrive mails og breve til politikeren, de må oprette blogs, hvor de forsøger at overbevise ham om rigtigheden af netop deres synspunkt, de må sende læserbreve til aviserne, ja de ikke bare må, de er næsten forpligtede til at anvende deres ytringsfrihed i et for dem centralt emne. Men de må ikke stikke ham 1.000 kr. Gør de det, kan de i stedet for at få ros, blive puttet i fængsel. Vi er ikke i tvivl om, at det vil være "uberettiget" og strafværdigt.

Mellem disse to poler findes et utal af varianter: han modtager blomsterbuketter med tydelig angivelse af afsenderen og ønske om "det rigtige valg i en svær situation", han inviteres til at holde foredrag for et stort honorar, o.s.v.

I eksempel 3 i afsnit 1 ydede en virksomhed tilskud til de politiske partier, der var repræsenteret $\mathrm{i}$ byrådet, umiddelbart inden dette skulle tage stilling til ændring af en lokalplan, som virksomheden havde et stærkt ønske i. Dette vil helt 
utvivlsomt blive opfattet af omverdenen som et forsøg på at påvirke politikerne til at indtage en bestemt holdning, og det var sandsynligvis også tænkt således fra virksomhedens side. Det afgørende er imidlertid, om virksomheden vælger et påvirkningsmiddel, der er strafbart, og svaret herpå afhænger af, om der er tale om uberettiget fordel. Der er tale om ydelse af penge og der er tale om penge til noget som politikeren må formodes at have en stærk interesse i. Dette taler for, at det er uberettiget. På den anden side er det i langt de fleste lande helt legalt generelt at yde tilskud til politiske partier blandt andet ud fra en betragtning om, at det styrker demokratiet at partierne har midler til rådighed.

I Danmark er der således en lov $^{16}$, der pålægger politiske partier at offentliggøre deres regnskab med angivelse af bidrag fra private, faglige organisationer, virksomheder m.v., og såfremt det samlede bidrag fra den enkelte giver det pågældende år overstiger $20.000 \mathrm{kr}$. skal navnet på yderen tillige fremgå af regnskabet. Denne lov gælder imidlertid kun udtrykkeligt for bidrag til partier, der er repræsenteret i Folketinget og i Europaparlamentet og regnskabspligten vedrører alene partiernes landsorganisation. Der er således ikke pligt til at oplyse om bidrag til lokale vælgerforeninger med videre. Baggrunden herfor var alene, at partierne var organiseret forskelligt på lokalt plan og at det ikke var rimeligt at pålægge disse små foreninger, hvoraf mange var baseret på frivilligt, ulønnet arbejdskraft en egentlig regnskabspligt ${ }^{17}$.

Man må således også i vurderingen af om støtten i eksempel 3 er uberettiget (og dermed potentielt strafbar som bestikkelse), inddrage det forhold, at lovgiver faktisk har reguleret området og undladt at kræve oplysninger i et tilfælde som det foreliggende. Når lovgiver har forholdt sig til reguleringen af disse - helt legale - tilskud, har det klart formodningen imod sig, at det skulle kunne være strafbar bestikkelse at give et sådant bidrag. Det forhold alene, at der er tidsmæssig sammenhæng mellem ydelsen af tilskuddet og beslutningen i byrådet kan næppe i sig selv føre til en ændret vurdering.

I hvert fald efter dansk ret vil eksempel 3 klart være et tilfælde, hvor bestikkelsesreglen ikke er overtrådt. Resultatet ville utvivlsomt have været omvendt, hvis de enkelte politikere i byrådet personligt havde modtaget en check på hver $20.000 \mathrm{kr}$. fra firmaet.

Hvor der ikke findes sådanne legale holdepunkter for udfyldningen af ordet uberettiget, er man i høj grad henvist til en friere vurdering, hvori også indgår spørgsmålet om hvorledes den almindelige norm i en given sammenhæng er. I Danmark har man eksempelvis haft store vanskeligheder ved at afgrænse det område, hvor offentligt ansatte gerne må modtage gaver og er landet på at straffri situationer i hvert fald er mindre gaver i anledning af særlige jubilæer, fødselsdage eller lignende ${ }^{18}$. 
Når udfyldelsen af begrebet uberettiget kan give anledning til så store afgrænsningsproblemer $i$ et homogent og normalt bestikkelses frit land som Danmark, er det indlysende, at vanskelighederne kan eksplodere ved anvendelse af reglerne i fremmede lande, hvor kulturen og samfundsstrukturen er en ganske anden og hvor bestikkelse på alle niveauer nok er forbudt ved lov, men særdeles udbredt i praksis ${ }^{19}$.

I Danmark skrev Justitsministeriet da også således i bemærkningerne til lovforslaget om ændring af reglerne om bestikkelse ${ }^{20}$ :

Selv om gerningsindholdet ved den foreslåede ændring er det samme ved bestikkelse af udenlandske tjenestemænd mv. som ved bestikkelse af danske tjenestemænd, kan det ikke udelukkes, at der i nogle lande kan gøre sig sådanne helt særlige forhold gældende, at visse erkendtligheder efter omstændighederne vil falde uden for det strafbares område, selv om de ville udgøre strafbar bestikkelse, hvis det var foregået her i landet. Dette vil endog kunne tænkes, selv om erkendtlighederne måtte være ydet for at få den fremmede tjenestemand til at handle pligtstridigt. Om sådanne forhold er straffri (ikke »uberettiget«) må bero på en konkret vurdering i det enkelte tilfælde, herunder af formålet med at yde erkendtligheden.

Et eksempel på en sådan kollision er systemet med "smørepenge":

\section{Small facilitation payment}

I eksempel 2 i afsnit 1 betaler kaptajnen på et skib 10 USD til den lokale havefoged for at få udstedt en tilladelse til at anløbe havnen. Dette er som udgangspunkt - og ganske indlysende - omfattet af ordlyden af reglerne om strafbar bestikkelse $i$ alle de nordiske lande.

Som omtalt i afsnit 2 er der imidlertid tale om en såkaldt "small facilitation payment", og derfor uden for området af OECD-konventionen. Som citeret i afsnit 2, er begrundelsen for denne eksklusion, at der tale om en adfærd, der er ganske normal i en del lande, og at man ikke bør imødegå sådan uheldig adfærd gennem foreskrivelse af straf fra udlandets side. Man bør i stedet forsøge at få landet til at indføre regler om good governance m.v.. Med andre ord et af de tilfælde, der efter OECD's opfattelse ligger i det område, hvor adfærden nok er uheldig og uønskelig, men hvor den ikke bør indebære anvendelse af straf.

De øvrige konventioner - herunder Europarådets - omtaler imidlertid ikke disse små ydelser (smørepenge). Denne undladelse kan skyldes, at man ikke ønsker at "afkriminalisere" et meget stort område, at man er bange for at det kan give væsentlige afgrænsningsvanskeligheder eller at man er uenig med OECD i, at foreskrivelse af straf er et problem i disse tilfælde. Endelig kan det naturligvis være et udtryk for, at sådanne smørepenge må behandles indenfor vurderingen af ordet "undue" og at det således må afhænge af en konkret vurdering i hvert enkelt tilfælde, hvorvidt der er tale om strafbar bestikkelse eller ikke. 
I henhold til Europarådets konvention kan landene tage forbehold, således at de alene forpligter sig til at straffe, hvor der er tale om, at den offentligt ansatte betales for at handle i strid med sine pligter. Muligheden af at tage sådant forbehold drøftedes i Norge i forbindelse med overvejelser om small facilitation payment, men Norge ønskede ikke at tage et sådant generelt forbehold. Efter at have konstateret dette, fortsatte teksten i proposisjonen ${ }^{21}$ :

\begin{abstract}
»Dette betyr ikke at «facilitation payments» i utlandet alltid gir grunnlag for å straff etter forslaget til ny $\S 276$ a. Slike handlinger skal bare være straffbare dersom fordelen som tilbys eller gis den utenlandske offentlige tjenestemannen, er utilbørlig. En del slike betalinger kan ikke karakteriseres som utilbørlige, for eksempel dersom situasjonen bærer preg av utpresning. Den som ser seg tvunget til å betale en utenlandsk offentlig tjenestemann et mindre beløp for å få tilbake passet sitt, eller for å få lov til å reise ut av landet, kan derfor ikke straffes etter forslaget. For øvrig må det også i disse situasjonene utøves et skjønn, hvor sentrale momenter vil være ytelsens verdi, samt om den bryter med lov eller sedvane.«
\end{abstract}

Jeg er helt enig i, at disse betragtninger som oftest vil føre til, at det ikke er "uberettiget" at betale sådanne mindre smørepenge. Fordelen ved ikke helt generelt at undtage disse smørepenge er endvidere, at det retlige udgangspunkt vil være, at det er strafbart. På denne måde undgås en almindelig holdning om, at man som person eller virksomhed roligt kan betale bestikkelse, når blot der er tale om mindre beløb, og det foregår et sted, hvor noget sådant er udbredt.

\title{
6. Afrunding
}

Der er en høj grad af homogenitet i de nordiske landes strafferegler om bestikkelse. Der er også en høj grad af homogenitet landene imellem på kulturelle, sociale og juridiske områder i øvrigt. Dette giver os unik mulighed for at lære af hinanden generelt og på dette konkrete område at lære og blive inspireret af hinandens lovgivning, retspraksis ${ }^{22} \mathrm{og}$ andre måder at reducere risikoen for korruption såvel nationalt som i udlandet.

Som beskrevet $\mathrm{i}$ indledning er korruption er mangefacetteret fænomen, som kan og bør begrænses på mange forskellige måder. I nærværende artikel har det udelukkende været den strafferetlige regulering, der har været genstanden, men forvaltningsretlige regler om inhabilitet (jäv) og civilretlige konsekvenser i form af ugyldighed, tilbagelevering og erstatning er nogle af juraens andre instrumenter til at begrænse risikoen for og virkningerne af korruption i bred forstand.

Et eksempel på en offentligretlig konsekvens kunne være EU's udbudsdirektiv $^{23}$, hvor artikel 45, stk. 1, litra b, udelukker ansøgere og tilbudsgivere, der har en endelig dom for bestikkelse fra at deltage $\mathrm{i}$ en udbudsprocedure ${ }^{24}$. Uanset at der kan stilles mange og berettigede spørgsmål ved en sådan efterfølgende rettighedsfrakendelse, er den et udmærket eksempel også på den fokus, der findes flere og flere steder, på ønsket om at forhindre korrupt adfærd. 


\section{Litteratur:}

Andences, Johs. v/ Kjell V. Andersson: Speciell strafferett og formuesforbrytelsene, samlet utgave. Universitetsforlaget 2008 (2. oplag 2009)

Fog, Morten Quist \& Steinicke, Michael: Udbudsreglerne og bestikkelse, Juristen 2009, nr. 10, s. $280 \mathrm{ff}$.

Langsted, Lars Bo: Bestikkelse - og det, der ligner i Jurist Uden Omsvøb - Festskrift til Gorm Toftegaard Nielsen, Christian Ejlers' Forlag 2007

Langsted, Lars Bo: Bribery, Bribery across Borders and the Like from a Danish Perspective i Scandinavian Studies in Law, Volume 54, Criminal Law, 2009

Meyer Olaf (ed.): The Civil Law Consequences of Corruption, Schriftenreihe des Zentrum für Europäische Rechtspolitik (ZERP), Band 53, Nomos 2009

\section{Noter:}

Se f.eks. første protokol til EU-svigskonventionen fra 1995 (Konventionen om beskyttelse af De Europæiske Fællesskabers finansielle interesser), for det andet EU-bestikkelseskonvention fra 1997 (Konventionen om bekæmpelse af bestikkelse, der involverer tjenestemænd ved De Europæiske Fællesskaber eller i Den Europæiske Unions medlemsstater), for det tredje OECD bestikkelseskonvention ligeledes fra 1997 (OECD-konventionen om bekæmpelse af bestikkelse af udenlandske tjenestemænd i forbindelse med internationale forretningstransaktioner), for det fjerde EU's fælles aktion af 22. december 1998 (vedtaget af Rådet på grundlag af artikel K.3 i traktaten om Den Europæiske Union om bestikkelse i den private sektor) og for det femte Europarådets korruptionskonvention fra 1999 (Europarådets strafferetskonvention om korruption).

Det seneste nummer af Verdensbankens »fast brief« vedrørende Mellemøsten og Nordafrika handlede f.eks. om mulighederne af at måle korruption. Verdensbanken har tidligere fastslået, at korruption skader demokratiet og er økonomisk ødelæggende for det enkelte land.

2 I en situation, hvor man f.eks. gerne vil have fodboldinteressen blandt unge til at vokse ved at ønske at etablere en klub i et socialt belastet område, har man en ideel, samfundsgavnlig interesse - men det bliver således også en del af ens »egeninteresse« at pleje og understøtte denne klub.

3 Se således Kommentarerne til konventionen (som vedtaget på "the Negotiating Conference on 21 November 1997"), punkt 4, hvor det hedder: »It is an offence within the meaning of paragraph 1 to bribe to obtain or retain business or other improper advantage whether or not the company concerned was the best qualified bidder or was otherwise a company which could properly have been awarded the business. [min fremhævelse]

4 Ud fra en ordlydsfortolkning giver dette dog ikke megen mening, og man kan vel også spørge om det at opnå en fordel (»advantage«), som ikke består i en forretningsaftale eller tilladelse (»business«), skulle være mindre slemt end det at opnå en tilladelse eller kontrakt , man I øvrigt er berettiget til.

Punkt 9.

ETS No. 173

Se således Explanatory Report til konventionen, punkt 65, hvor det siges: »'Improper" influence must contain a corrupt intent by the influence peddler: acknowledged forms of lobbying do not fall under this notion.«

Idet Danmark dog har taget forbehold for Færøerne og Grønland.

Jeg har ikke medtaget bestemmelser, der særskilt nævner f.eks. anvendelse af bestikkelsesregler på parlamentsmedlemmer eller på udenlandske embedsmænd m.v., idet de persongrupper, der samlet set omfattes af reglerne om bestikkelse i de nordiske lande, stort set er de samme. 
Det vil derfor blot føre til yderligere uoverskuelighed at søge at have fuldstændigt dækkende henvisninger i samtlige celler i tabellerne.

10 Begreberne "aktiv" og "passiv" bestikkelse er ikke ganske velvalgte, idet modtageren af bestikkelsen således begår "passiv" bestikkelse, selvom det er ham eller hende, der har taget hele initiativet til bestikkelsen - som f.eks. i eksempel 1. Se nærmere om sprogbrugen vedrørende disse og andre "korruptionsbegreber", Lars Bo Langsted i Festskrift til Gorm Toftegaard Nielsen (2007), s. $218 \mathrm{f}$.

11 Se f.eks. Andences, samlet udgave v. Kjell V. Andorsen (2009), s. 423. Dette er tillige nævnt direkte i forarbejderne til loven (OT. prp. 78 (2002-2003)).

12 Se bekræftende for Sveriges vedkommende: Regeringens proposition 2003/04:70, s. 33.

13 Se for en tilsvarende fortolkning af den norske bestemmelse, Andences, samlet udgave v. Kjell V. Andorsen (2009), s. 427.

14 Jf. også OT.prp. 78 (2002-2003), s. 60, højre spalte: »Nærstående av stortingsrepresentanter og andre i posisjoner som det er viktig å opprettholde tilliten til, må derfor finne seg i å være underlagt en streng norm.«

15 Bl.a. fordi civilretlige remedier ikke i sig selv opleves som tilstrækkelige. Der vil således ofte være bestikkelsessager, hvor ingen har lidt noget tab, og hvor "erstatningssanktionen" derfor ikke kan anvendes, ligesom mulig ugyldighedsstatuering af aftaler, der er indgået i forbindelse med bestikkelse, nok er fornuftig, men hvor det for en civil part vil kunne være endog ekstremt vanskeligt at sandsynliggøre den stedfundne bestikkelse m.v.

Se i øvrigt den meget interessante antologi: "The Civil Law Consequences of Corruption" af Olaf Meyer (red.).

16 Lovbekendtgørelse 1123 af 24/10 2006 om private bidrag til politiske partier og offentliggørelse af politiske partiers regnskaber.

17 Se de generelle bemærkninger i LFF 1990-02-08 nr. 179 Forslag til Lov om private bidrag til politiske partier og offentliggørelse af politiske partiers regnskaber.

18 Se nærmere Lars Bo Langsted i Festskrift til Gorm Toftegaard Nielsen, 2007, s. 222 ff.

${ }^{19}$ Se f.eks. Lars Bo Langsted, Bribery, Bribery across Borders and the Like from a Danish Perspective, s. $247 \mathrm{ff}$.

20 Lovforslag L 15, 1999-2000, Bemærkninger til lovforslagets enkelte bestemmelser til § 1, til nr. 3 .

$21 \quad$ Ot.prp. nr. 78 (2002-2003), s. 36.

22 Jeg har desværre været nødt til at fravælge anvendelsen af retspraksis i denne oversigtsartikel om reguleringen af korruption i de nordiske lande. Et projekt i naturlig forlængelse af denne artikel kunne være at undersøge retspraksis fra de enkelte nordiske lande for at se, hvorledes reglerne faktisk anvendes.

23 Direktiv nr.2004/18/EF

24 Se om bestemmelsen nærmere Morten Qvist Fog og Michael Steinicke: "Udbudsreglerne og bestikkelse"

Adresse:

Juridisk Institut

Aalborg Universitet 